\title{
Farklı Kişilik Özelliklerinin Turizmde Sürdürülebilir Çevre Davranışlarına Etkisi
}

The Effect of Different Personal Traits on The Sustainable Environmental Behavior in Tourism

\author{
Uğur CEYLAN \\ **Dr. Öğr. Üyesi., Kütahya Dumlupınar Üniversitesi, Tavşanlı Uygulamalı Bilimler Fakültesi, Turizm ve Otel İşletmeciliği Bölümü, Balıkesir Yolu 3. Km, 43300, \\ Tavşanlı, Kütahya. \\ E-posta: ugur.ceylan@dpu.edu.tr \\ ORCID: 0000-0001-6078-8424
}

MAKALE BILGILERI

Makale işlem bilgileri:

Gönderilme tarihi: 24 Nisan 2019

Düzeltme: 1 Temmuz 2019

Düzeltme: 23 Temmuz 2019

Kabul: 29 Temmuz 2019

Anahtar sözcükler: Beş faktör kişilik özellikleri, Sürdürülebilir çevre davranışları, Turist, Paket tur, Turizm.

\section{ARTICLE INFO}

Article history:

Submitted: 24 April 2019

Resubmitted: 1 July 2019

Resubmitted: 23 July 2019

Accepted: 29 July 2019

Key words: Five factor personality traits, Sustainable environmental behavior, Tourist, Package tour, Tourism.

\section{ÖZ}

Turistlerin gittikleri destinasyonda çevrenin sürdürülebilirliği için yapmış oldukları tutum ve davranışlar önemlidir. Turizmde çevrenin sürdürülebilirliğinin sağlanması ve gelecek nesillere aktarılması önemli bir konudur. Bu araștırmada turistlerin beş faktör kișilik özelliklerinin, turizmde sürdürülebilir çevre davranışları üzerindeki etkisi incelenmiştir. Araştırmada İstanbul'da faaliyet gösteren bir seyahat acentasıyla Eylül 2018 tarihinde yurt dışına çıkan 486 yerli turiste anket tekniği uygulanmıştır. Araştırmanın sonuçlarına göre uyumluluk, duygusal denge ve deneyime açıklık kișilik özelliklerinin sürdürülebilir çevre davranıșları üzerinde bir etkisinin olmadığı, dışa dönüklük ve sorumluluk kişilik özelliklerinin ise sürdürülebilir çevre davranışları üzerinde anlamlı bir etkiye sahip olduğu bulunmuştur. Araştırmanın diğer sonuçları sonuç ve tartışma kısmında değerlendirilmiştir.

\section{GiRiş}

Turizm faaliyetlerinin destinasyonlar üzerinde birçok olumsuz çevresel etkisi bulunmaktadır. Bu etkiler destinasyonları ekonomik, sosyal ve çevresel olarak etkilemektedir. Olumsuz etkilerin ortadan kaldırılmasına yönelik olarak hükümetler çok az önleyici faaliyette bulunmaktadırlar. Bunun da başlıca sebebi hem turizm talebini etkilemesi hem de turizm gelirlerini azaltmasıdır. Benzer şekilde turizm sektörü de işletme giderlerinin artması nedeniyle sürdürülebilir tedbirlerin uygulanmasında fazla çaba göstermemektedir. Bu nedenle turistler, turizmin çevresel sürdürülebilirliğini arttırmaya çalışan en umut verici hedefi temsil etmektedirler. Turistler, bu olumsuz etkinin azaltılmasına, çevreye duyarlı tatil kararları vererek ve varış yerlerinde çevreye duyarlı bir şekilde davranarak yardımcı olmaktadırlar (Juvan ve Dolnicar 2016: 30-31).

Turistler her ne kadar çevreye duyarlı bir şekilde hareket etseler de kitlesel turizm hareketleri tamamıla tüketim temelli olması ve çevre üze- 
rinde birçok olumsuz etki oluşturması nedeniyle turizmde sürdürülebilirlik konusu gündeme gelmiştir. Yerel toplumun ve ziyaretçilerin sürdürülebilir çevre üzerinde etkisi oldukça fazladır. Dolayısıyla turizmde sürdürülebilir çevre davranışları açısından toplumsal ve bireysel olarak öncelikli olarak zihniyet değişiminin sağlanması öncelikli konulardan biridir (Çalışkan 2017: 1124).

Turistler, gittikleri destinasyonda bilinçli ya da bilinçsiz olarak çevre üzerinde olumsuz etkilerde (çevre ve gürültü kirliliği, vahşi yaşamın bozulması, kalabalık vb.) bulunabilirler. Turistler çevreye karşı bu olumsuz tutum ve davranışlarını değiştirirlerse, çevre üzerindeki olumsuz etkiler azalacaktır. Çevrenin korunması ve restorasyonu günümüzde insanlığın önündeki en önemli risklerdir. Bu nedenle turizmde sürdürülebilir çevre davranışlarını nelerin ve hangi faktörlerin etkilediği önemli bir konudur (Islam ve Managi 2019: 127).

Turizmde sürdürülebilir çevre için turistlerin gittikleri destinasyonlarda çevreye karşı duyarlı davranmaları gerekmektedir. Kendi ev sahibi oldukları destinasyonda nasıl davranıyorlarsa gittikleri destinasyona da bu davranışları taşımaları gerekmektedir. Alanyazında beş faktör kişilik özellikleri ile turizmde sürdürülebilir çevre davranışları arasındaki ilişkiyi ölçen araştırmanın sınırlı olduğu görülmektedir. Ulaşılabilen bu kaynaklar da paket turlar ve yurt dışına çıkan turistlerle doğrudan ilgili değildirler. Ulaşılabilen kaynaklar kuram bölümünde verilmiştir. Bu açıdan araştırmanın alanyazına önemli bir katk1 sağlayacağı düşünülmektedir. Araştırmada yurt dışına çıkan yerli turistlerin beş faktör kişilik özelliklerinin, turizmde sürdürülebilir çevre davranışları üzerindeki etkisi incelenmiştir.

\section{KURAM}

\section{Beş Faktör Kişilik Özellikleri}

Kişilik kavramı alanyazında birçok şekilde tanımlanmıştır. Somer'e (1998) göre kişilik tanımlarının birçoğunda ortak nokta, farklı durumlarda tutarlılık göstermeleri, uzun süreli eğilimler olmaları ve içsel nedenler olarak değerlendirilmeleridir. Weinstein, Capitanio ve Gosling (2008) tarafından yapılan tanımlamaya göre kişilik "bireylerin istikrarlı bir örüntü gösteren duygular1nı, düşüncelerini ve davranışlarını tanımlayan ve açılayan bireysel özelliklerdir". Hogan (2009) ise kişiliği, "kişilerarası farklılığı ortaya koyan önemli bir faktör olarak görmekte ve kişiliğin oluşmasında genetik ve çevresel faktörlerin etkili olduğunu" ifade etmektedir (Aslan vd. 2012: 204).

1937 yılında Allport tarafından geliştirilen Kişilik Özellik Teorisi, Beş Faktör Kişilik Özellikleri Modeli'nin temelini oluşturur. Beş kişilik özelliğinin yer aldığg bu modelde kişilik özellikleri şu şekilde belirlenmiştir; uyumluluk (agreeableness), sorumluluk (conscientousness), dişa dönüklük (extraversion), duygusal denge (neuroticism) ve deneyime açıklık (openness to experience) (McCabe vd. 2013: 698). Kişilik özellikleri, 1966 yılında Allport ve Odbert tarafından araştırılmaya başlanmıştır. Daha sonra Cattel, kişilik özelliklerini 16 boyutta, Eysenk ise içe dönüklük ve dışa dönüklük olmak üzere iki boyutta açıklamaya çalışmıştır. 1978 ve 1980 yıllarında Robert R. McCrea ve Paul T. Costa'nın çalışmalarında deneyime açıklık boyutunu, içe dönüklük ve dışa dönüklük boyutlarına ilave olarak eklemişlerdir. 1987 yılında ise son iki boyut olan uzlaşmacılık ve vicdanlılık (sorumluluk) boyutlarını ekleyerek, eleştiriler doğrultusunda çalışmalarını da genişleterek "Büyük Beş Faktör" kuramını ortaya koymuşlardır (Çetin 2018: 56). Alanyazında kişilik özelliklerinin sınıflandırmasına yönelik kullanılan en yaygın sınıflandırma Büyük Beş Faktör (dışa dönüklük, uyumluluk, duygusal denge, deneyime açıklık ve sorumluluk) kişilik özellikleridir. Bu faktörlerin özellikleri Tablo 1'de verilmiştir.

\section{Turizmde Sürdürülebilir Çevre Davranışları}

Sürdürülebilir turizm, turizm endüstrisi, ziyaretçiler, çevre ve tatilciler ile yerel halk arasındaki karmaşık etkileşimlerin yarattığı olumsuz havayı azaltmayı amaçlayan bir yaklaşımdır. Hem doğal hem de insan kaynağının uzun vadeli devamlılığ 1 ve kalitesi için çalışmayı kapsayan bir yaklaşımdır. Bu yaklaşım büyüme karşıtı değildir, ancak büyümenin sınırlarının olduğunu kabul etmek- 
Tablo 1. Kişilik Boyutlarının Özellikleri

\begin{tabular}{ll}
\hline Kişilik Boyutu & Özellikleri \\
\hline Dışa Dönüklük & $\begin{array}{l}\text { Sosyal, enerjik, heyecanlı, konuşkan, sıcakkanlı, olumlu duygulara sahip, diğerlerinin } \\
\text { teşvik eden. }\end{array}$ \\
\hline Uyumluluk & $\begin{array}{l}\text { Sempatik, sevecen, sıcakkanlı, cömert, saygılı, arkadaş̧ııl, yardımsever, uzlaşmacı, iyimser, } \\
\text { insanların güvenilir olduğunu düşünen, alçak gönüllü, hemfikir olmaya meyilli, } \\
\text { karşısındakinin çıkarlarını düşünen, esnek, güvenilir, iş birliği taraftarı, anlayışlı, yumuşak kalpli. }\end{array}$ \\
\hline Öfkeli, endişeli, güvensiz, kendisiyle uğraşan, sinirli, kaygıılı, bunalımlı olma, problemli olma, \\
mutsuz olma, depresif, sıkılmış, duygusal, üzgün ve diğerlerine güvenmeyen, duygusal \\
iniş- çıkışlar, tedirginlik, huzursuzluk ve sabırsılık, düşmanlık, kırılganlık, negatif duyguları \\
deneyimleme eğilimli, başa çıkma mekanizmalarındaki yetersizlik.
\end{tabular}

Kaynak: Norman 1963; Goldberg 1990; Costa ve McCrae 1990; Barrick ve Mount 1991; Church vd. 1997; Somer 1998; Ashton ve Lee 2008; Öztürk 2016.

tedir (Bramwell ve Lane 1993: 2). Sürdürülebilir turizm kavramının farklı çıkar grupları için farklı anlamları vardır ve bu anlamlar kültür, eğitim veya geçmiş gibi bireysel özellikler ile örgütsel bağlılık veya siyasi duruma bağlıdır. Sürdürülebilir turizm için birçok tanım verilmiştir, ancak tüm yazarların ortak fikir birliği sağladığı tanım, Dünya Turizm Örgütü (WTO) tarafından yapılan; "Mevcut, gelecekteki sosyal, ekonomik ve çevresel etkileri tam olarak dikkate alan, ziyaretçilerin, endüstrinin, çevre ve ev sahibi toplulukların gereksinimlerini ele alan turizm" tanımıdır (Pulido-Fernandez vd. 2019: 310). Sürdürülebilir turizm, uygulanabilir, etkileri ölçülebilir, gerektiğinde kaçınılmaz sonuçlar ortaya çıkardığında düzeltici ve önleyici önlemlerin alınması gerekli bir durumdur. Sürdürülebilir turizm istisnai bir turizm şekli olarak değil, tam tersine turizmin tüm paydaşlarının içerisinde sürdürülebilir olduğu bir harekettir (Asmelash 2019: 68).

Çevresel olarak sürdürülebilir turist davranışı birçok şekilde tanımlanmıştır. Bu tanımlar incelendiğinde; Krippendorf (1987: 74) “Sağllk, çevre gibi önemsiz görülen değerlerin önemi konusunda artan bir farkındalığa sahip bilgilendirilmiş ve deneyimli turistler", Wood ve House (1992: 101)," Destinasyon üzerinde olumsuz bir etkiye sahip olmaktan kaçınması gereken bir turist",
Dinan ve Sargeant (2000: 7), “Başka birinin kültüründe, toplumunda, çevresinde ve ekonomisinde ziyaretçi olduğu fikrini takdir eden ve seyahatin bu eşsiz özelliğine saygı duyan biri", Perkins ve Brown (2012: 795) "Turizmde çevre sorumluluğuna ve yeşil turizm tedarikçilerine daha fazla destek veren, güçlü çevre değerlere sahip olan gezginler", Juvan ve Dolnicar ( 2016: 31) "çevresel açıdan sürdürülebilir turist davranışı, hem küresel olarak hem de varış noktasında doğal çevreyi olumsuz yönde etkilemeyen (ya da çevreye fayda sağlayabilecek) turist davranışı" şeklinde tanımlamışlardır.

Turizmin; doğal çevreye zarar vermesi, gürültü kirliliği ve trafik karmaşası yaratması, çevre kirliliğinin arttırması, doğal kaynakların olumsuz etkilenmesi ve turistik değerlere zarar verilmesi gibi birçok olumsuz etkisi bulunmaktadır (Bertan 2009: 206). Çevresel sürdürülebilirlik, doğal kaynaklara asgari düzeyde zarar vermek için kaynak tüketimini ve israfı azaltmak gibi davranışları gerektirir; geri dönüşüm, 1şıkları söndürme, çevrenin kalitesini korumak için yeşil ürünler tüketmek gibi. Turistler mümkün olan en küçük küresel ekolojik ayak izine neden olmalıdır (Kastenholz vd. 2018: 134). Turistler genellikle gittikleri destinasyonda çevreye karşı olumlu tutum ve davranışlara sahip olup çevreyi olumsuz yön- 
de etkileyecek şekilde davranmak istememektedirler. Sürdürülebilir çevre davranışı açısından olumlu tutuma sahip olmak, çevresel açıdan sürdürülebilir tatil seçimlerini yapmanın iyi bir göstergesi olarak ortaya çıkmamaktadır (Juvan ve Dolnicar 2014: 76). Bu nedenle, bu problemleri hafifletmek için insan davranışlarını yönlendiren faktörlerin belirlenmesi esastır. Bireylerin neden çevre yanlısı davranış başlattığına ilişkin detayların belirlenmesi karar vericiler ve araştırmacılar için tutumların değişimini gerektiren çevresel zorlukların çözümünü belirlemek için şarttır (Clark vd. 2003).

Turizmde sürdürülebilir çevre davranışlarına yönelik son yıllarda yapılan çalışmalar incelendiği zaman, çalışmaların genellikle turistlerin gittikleri destinasyonda çevre dostu tutum ve davranışları (Avcıkurt vd. 2017; Karaca 2018), çevreye karşı duyarlılıkları (Altanlar ve Akıncı Kesim 2014; Wang vd. 2018; Wang vd. 2019) ve destinasyonlarda sürdürülebilir enerji kaynakları (Islam ve Managi 2019), turizmin gelişimi ve çevresel sürdürülebilirlik arasındaki ilişkiler (Sheldon ve Park 2011; Su vd. 2018; Pulido-Fernandez vd. 2019) üzerine olduğu görülmektedir. Çalışmaların daha çok destinasyonlardaki uygulamalara ve turistlerin tutum ve davranışlarına yönelik olması, bu çalışmanın önemini biraz daha artırmaktadır.

\section{ILGILI ÇALIŞMALAR}

Beş faktör kişilik özellikleri ile sürdürülebilir çevre davranışları üzerine yapılan araştırmalar incelendiğinde, bu araştırmaların oldukça sınırlı olduğu fark edilmiştir. Alanyazın kısmında kavramlara yönelik araştırmalar yer almasına rağmen, bu iki kavram arasında ilişkiyi ya da etkiyi ölçmeye yönelik çalışmaların oldukça sınırlı olduğu görülmektedir. Hirsh (2010), çalışmasında uyumluluk ve vicdanlılık kişilik özelliklerinin çevresel kaygı üzerinde olumlu etkilerini ortaya koymuştur. Milfont ve Sibley (2012) çalışmalarında beş faktör kişilik özelliklerinin çevre ile uyumunu incelemiş ve araştırmaları sonucunda uyumluluk, sorumluluk ve deneyime açıklık kişilik özelliklerinin, kişilerin çevre ile uyumlarında önemli kişilik özellikleri olduğunu orta- ya koymuşlardır. Kvasova (2015) turistler üzerine yapmış olduğu çalışmada beş faktör kişilik özelliklerinin sürdürülebilir çevre davranışları üzerinde etkisini incelemiş ve dişa dönüklük, uyumluluk, duygusal denge, sorumluluk kişisel özelliklerinin sürdürülebilir çevre davranışları üzerinde olumlu etkisi bulunurken, deneyime açıklık kişilik özelliğinin sürdürülebilir çevre üzerinde etkisi ortaya çıkmamıştır. Yu ve $\mathrm{Yu}$ (2017) çalışmalarında beş faktör kişilik özelliklerinin sürdürülebilir çevre üzerinde etkilerini incelemişler ve uyumluluk ile duygusal denge kişilik özellikleri ile sürdürülebilir çevre arasında olumlu bir etkinin olduğunu ortaya koymuşlardır. Alanyazında yer alan yukarıdaki çalışmalar da dikkate alınmak suretiyle aşağıdaki hipotezler geliştirilmiştir:

$\mathrm{H}_{1}$ : Turistlerin dışa dönüklük kişilik özelliği, turizmde sürdürülebilir çevre davranışlarını pozitif yönlü olarak etkilemektedir.

$\mathrm{H}_{2}$ : Turistlerin uyumluluk kişilik özelliği, turizmde sürdürülebilir çevre davranışlarını pozitif yönlü olarak etkilemektedir.

$\mathrm{H}_{3}$ : Turistlerin duygusal denge kişilik özelliği, turizmde sürdürülebilir çevre davranışlarını pozitif yönlü olarak etkilemektedir.

$\mathrm{H}_{4}$ : Turistlerin sorumluluk kişilik özelliği, turizmde sürdürülebilir çevre davranışlarını pozitif yönlü olarak etkilemektedir.

$\mathrm{H}_{5}$ : Turistlerin deneyime açıklık kişilik özelliği, turizmde sürdürülebilir çevre davranışlarını pozitif yönlü olarak etkilemektedir.

\section{YÖNTEM}

\section{Veri Toplama Aracı}

Araştırma için anket tekniği kullanılmıştır. Araştırma için hazırlanmıș olan anket formu iki bölümden oluşmaktadır. Birinci bölümde katılımcıların demografik özelliklerini belirlemeye yönelik beş soru sorulmuștur. İkinci bölümde beşli likert (1-Kesinlikle Katılmıyorum ... 5- Kesinlikle Katılıyorum) şeklinde hazırlanan ve katılımcıların beş faktör kişilik özelliklerini ölçmeye yönelik olarak hazırlanmış 44 soru ve turizmde sürdürülebilir çevre davranışlarını ölçmeye yönelik yedi 
soru yer almaktadır. Beş faktör kişilik özelliklerini ölçmek için John vd. (1991) tarafından geliştirilen ve 44 ifadeden oluşan Büyük Beş Kişilik Ölçeği (The Big-Five Inventory) kullanılmıştır. Ölçeğin Türkçeye uyarlamasında Somer (1998) ve Akgündüz'ün (2015) çalışmasından yararlanılmıştır. Turizmde sürdürülebilir çevre davranışlarına yönelik hazırlanmış yedi soru Varnacı Uzun ve Altaş'ın (2017) çalışmalarından esinlenerek hazırlanmıştır.

\section{Evren ve Örneklem}

Araştırmanın evreni, İstanbul'da 14 yıldır faaliyet gösteren ve sadece yurt dışına yerli turist gönderen bir seyahat acentasının müşterilerinden oluşmaktadır. Seyahat acentasının 2018 yılında yurt dışına gönderdiği yerli turist sayısı 3400 kişidir. Araştırma için Eylül 2018 tarihinde 500 adet anket gönderilmiş ve bu anketlerden 486 tanesi analize uygun olarak değerlendirilmiştir. Geriye kalan 14 anket turistler tarafından eksik ve dikkatsiz doldurması nedeniyle değerlendirilmeye alınmamıştır. Araştırma kararsal (kasti) örnekleme yöntemiyle belirlenen 486 kişi üzerinde yürütülmüştür. Araştırma seyahat acentasıyla Eylül 2018 tarihinde yurt dışına çıkan yerli turistlerle sinırlıdır.

\section{Ölçeğin Geçerliliği ve Güvenilirliği}

Güvenilirlik, bir ölçme aracı ile benzer koşullarda tekrarlanan ölçümlerden elde edilen ölçüm değerlerinin kararlılığının bir göstergesidir (Kozak vd. 2014: 146). İçsel tutarlılığın ölçümünde en yaygın kullanılan yöntem Cronbach's Alfa olarak da bilinen alfa katsayısıdır. Bu amaç doğrultusunda Cronbach's Alfa değerini belirlemek amacıyla her bir faktör için geçerlilik ve güvenilirlik testi yapılmış ve Tablo 3'te verilmiştir.

Çarpıklık ve basıklık katsayılarının kendi standart hatalarına bölünmesi ile hesaplanan çarpıklık ve basıklık indekslerinin \pm 2 sınırları içinde 0 'a yakın olması normal dağılımın olduğunu göstermektedir. Her bir ölçek maddesinin çarpıklık ve basıklık değerlerine bakılmış ve çarpıklık değerlerinin $+1,448$ ile $-1,634$ sinırları içinde değerler

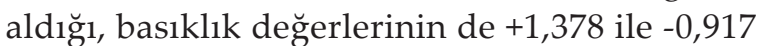
sınırları içinde yer aldı ğı ve dolayısıyla da ölçe- ğin çok değişkenli normallik varsayımını karşıladiğ1 görülmüştür.

Ölçeğin geçerliliğini ölçek amacıyla CR (Birleşik Güvenirlik) ve AVE (Ortalama Açıklanan Varyans) değerleri de incelenmiştir. Ölçeğe ilişkin tüm CR değerlerinin AVE değerlerinden büyük olması ve AVE değerinin de $0,5^{\prime}$ ten büyük olması beklenmektedir. Bu bağlamda her bir faktörün AVE değerlerine bakılmış olup, tüm faktörlerde de 0,5 değerinin üzerinde yer aldı ̆̆ı gözlemlenmiştir. Ayrıca her faktörün $C R$ değerlerinin de AVE değerlerinden yüksek olması ölçüm modelinin güvenilirliği sağladığı anlamına gelmektedir. $C R$ ve AVE değerleri Tablo 3'te verilmiştir.

Ölçüm modelinin geçerliliği, uyuşma ve ayrışma geçerlilikleri yönünden de incelenmiştir. Faktör analizi sonucunda her bir ölçek sorusunun sorunsuz bir şekilde faktörlere yüklenmesi ve 0,60 değerinden yüksek değer alması ölçeğin uyuşma geçerliliğini sağladığını göstermektedir. Bununla birlikte ayrışma geçerliliği yapılan analiz neticesinde değişkenler arasındaki korelasyon ilişkisinin anlamlı olduğu ve korelasyon değerlerinin 0,85 değerini aşmadığı görülmüştür.

\section{ANALIZ VE BULGULARIN YORUMLANMASI}

Araştırmaya katılanların yüzde 21,2'si 51 yaş ve üzeri kişilerden, yüzde 56,6's1 erkeklerden, yüzde 71,2' si evli çiftlerden, yüzde 50,8'i üniversite mezunlarından ve yüzde 55,3'ü özel sektör çal1şanlarından oluşmaktadır. Katılımcıların demografik özellikleri sıklık analizi ile belirlenmiş ve Tablo 2'de verilmiştir.

Faktör analizi üç aşamalı olarak gerçekleşmiştir. Yapılan ilk analiz sonucunda ölçekte yer alan 44 maddenin KMO değeri 0,676 ve anlamlılık değeri $p<0,001$ olarak bulunmuştur. Bu değerler verilerin faktör analizine tabi tutulabileceğini göstermektedir. İlk faktör analizinde 44 madde, altı faktör altında toplanmıştır ve özdeğeri 1'in üzerinde çıkmıştır. Fakat 2, 15, 21, 23, 37, 39 ve 43. maddelerinin birden fazla faktöre yüklenmesi sebebiyle faktör analizinden çıkartılmıştır. Kalan 37 madde ile ikinci bir faktör analizi gerçekleştirilmiştir. İkinci faktör analizinde 37 madde beş faktör altında toplanmıştır. KMO değeri 0,694 ve anlamlılık değeri $p<0,001$ olarak bulunmuştur. 
Tablo 2. Katılımcıların Demografik Özellikleri

\begin{tabular}{llrr}
\hline & & Sayı & Yüzde \\
\hline Yaş & 20 yaş ve altı & 41 & 8,4 \\
& 21-30 yaş & 94 & 19,3 \\
& 31-40 yaş & 107 & 22 \\
& 41-50 yaş & 141 & 29 \\
& 51 yaş ve üzeri & 103 & 21,2 \\
& Toplam & 486 & 100 \\
\hline Cinsiyet & Erkek & 275 & 56,6 \\
& Kadın & 211 & 43,4 \\
& Toplam & 486 & 100 \\
\hline \multirow{2}{*}{ Durum } & Evli & 346 & 71,2 \\
& Bekâr & 140 & 28,8 \\
& Toplam & 486 & 100 \\
Eğitim & Ilköğretim & 31 & 6,4 \\
Durumu & Lise & 146 & 30 \\
& Üniversite & 247 & 50,8 \\
& Lisansüstü & 62 & 12,8 \\
& Toplam & 486 & 100 \\
\hline \multirow{2}{*}{ Meslek } & Çalışmıyor/Ev hanımı & 40 & 8,2 \\
& Devlet Memuru & 86 & 17,7 \\
& Özel Sektör & 269 & 55,3 \\
& Serbest Meslek/ Kendi İşi & 60 & 12,3 \\
& Öğrenci & 31 & 6,4 \\
& Toplam & 486 & 100 \\
\hline & & &
\end{tabular}

İkinci faktör analizinde 4, 18, 29, 31 ve 41. maddelerinin birden fazla faktöre yüklenmesi nedeniyle faktör analizinden çıkartılmıştır. Kalan 32 madde ile üçüncü analiz gerçekleştirilmiştir. Üçüncü faktör analizinin KMO değeri 0,719 ve anlamlılık değeri $p<0,001$ olarak bulunmuştur. Bu maddeler beş faktöre sorunsuz bir şekilde yüklenmiştir. Bu faktörler "Dışa Dönüklük, "Uyumluluk", "Duygusal Denge", "Sorumluluk" ve "Deneyime Açıklık" şeklinde adlandırılmıştır. Faktör analizi sonuçları Tablo 3'te verilmiştir.

Turizmde sürdürülebilir çevre davranışlarına yönelik faktör analizi iki aşamalı olarak gerçekleştirilmiştir. Ölçekte yer alan yedi madde ile yapilan ilk analiz sonucunda KMO değeri 0,703 ve anlamlılık değeri $p<0,001$ olarak bulunmuştur. Birinci faktör analizinde yedi madde iki faktör altında toplanmıştır ve özdeğeri 1'in üzerinde çıkmıştır. Fakat 3. maddenin iki faktöre birden yüklenmesi nedeniyle faktör analizinden çıkartılmış- tır. Kalan altı madde için ikinci bir faktör analizi gerçekleştirilmiştir. İkinci faktör analizinin $\mathrm{KMO}$ değeri 0,764 ve anlamlılık değeri $p<0,001$ çımıştır. İkinci faktör analizinde altı madde, özdeğeri 1'in üzerinde tek faktör altında toplanmıştır. Faktör analizi sonuçları Tablo 4'te verilmiştir.

Tablo 4'te değişkenlere ait Cronbach's Alpha, standart sapma, ortalama ve ilişki değerleri verilmiştir. Tabloya göre turizmde sürdürülebilir çevre davranışları ile dışa dönüklük kişilik özelliği $(r=0,253 ; p<0,001)$; uyumluluk kişilik özelliği $(\mathrm{r}=0,537 ; \mathrm{p}<0,001)$; duygusal denge kişilik özelliği $(r=0,729 ; p<0,001)$; sorumluluk kişilik özelliği $(r=0,630 ; p<0,001)$ ve deneyime açıklık kişilik özelliği $(r=0,441 ; \mathrm{p}<0,001)$ arasında anlamlı pozitif ilişki olduğu bulunmuştur.

Yapilan normallik testleri (Kolmogorov-Smirnov ve Shapiro-Wilk) sonucunda dağılımının normal olmadığ görülmüştür $(p<0,05)$. Bu sonuca istinaden iki bağımsız değişken için MannWhitney U testi ve ikiden fazla seçenekli bağımsız değiş̧ken için Kruskal-Wallis H testi uygulanmasına karar verilmiştir.

Kadın ve erkeklerin sürdürülebilir çevre davranışlarının karşılaştırılması amacıyla yapılan Mann-Whitney U testi sonucunda kadın ve erkeklerin turizmde sürdürülebilir çevre davranışları arasında farklığın olduğu ortaya çıkmıştır $(\mathrm{p}=0,002<0,05)$. Katılımciların medeni durumları ile sürdürülebilir çevre davranışları arasında bir farklılık ortaya çıkmamıştır $(\mathrm{p}=0,144)$.

Katılımclların eğitim durumu ile sürdürülebilir çevre davranışları arasında farklılık gösterip göstermediğine yönelik olarak yapılan Kruskal-Wallis H Testi sonuçlarına göre eğitim durumuna göre anlamlı bir farklılığın olduğu ortaya çıkmıştır $(\mathrm{p}=0,040<0,05)$. Katılımcıların yaş ve meslek özelliklerine göre yapılan Kruskal-Wallis H Testi sonucunda katılımcıların yaş $(\mathrm{p}=0,322)$ ve meslek $(p=0,142)$ özellikleri arasında farklılığın olmadığ 1 ortaya çıkmıştır.

Araştırma kapsamında önerilen hipotezlerini test etmek amaciyla yapılan çoklu regresyon analizi sonuçları Tablo 5'te verilmiştir. Çoklu regresyon analizinde sürdürülebilir çevre davranışları bağımlı; beş faktör kişilik özellikleri ise bağımsız değişken olarak kabul edilmiştir. Bu şekilde beş 
Tablo 3. Beș Faktör Kişilik Özellikleri Faktör Analizi Sonuçları

\begin{tabular}{|c|c|c|c|c|c|c|}
\hline Faktörler & $\begin{array}{l}\text { Faktör } \\
\text { Yükleri }\end{array}$ & Özdeğer & $\begin{array}{c}\text { Açıklanan } \\
\text { Varyans (\%) }\end{array}$ & $\begin{array}{l}\text { Alpha } \\
\text { Değeri }\end{array}$ & $C R$ & $A V E$ \\
\hline Dışa Dönüklük & & 4,334 & 30,015 & ,715 & ,811 & ,592 \\
\hline Konuşkan biriyim. & ,718 & & & & & \\
\hline Dışa dönük, sosyal biriyim. & ,709 & & & & & \\
\hline Atılgan, girişken bir kişiliğe sahip biriyim. & 692 & & & & & \\
\hline Keşfeden, icat eden, yaratıcı biriyim. & ,688 & & & & & \\
\hline Heyecan yaratabilen biriyim. & 674 & & & & & \\
\hline Başkalarıyla sürekli tartışmaya giren biriyim. & ,613 & & & & & \\
\hline Çok değişik konuları merak eden biriyim. & 605 & & & & & \\
\hline Orijinal, yeni fikirler üretebilen biriyim. & 601 & & & & & \\
\hline Uyumluluk & & 3,437 & 22,631 & ,725 & ,902 & 614 \\
\hline Affedici bir yapıya sahip biriyim. & ,779 & & & & & \\
\hline Diğer insanlara güvenen biriyim. & ,762 & & & & & \\
\hline Herkese karşı nazik ve saygılı davranan birisiyim. & ,752 & & & & & \\
\hline Gergin ortamlarda sakin kalabilen biriyim. & ,703 & & & & & \\
\hline Güvenilir bir çalışan/iş gören/eleman olabilecek biriyim. & ,675 & & & & & \\
\hline Rahat, stresle kolay baş edebilen biriyim. & 663 & & & & & \\
\hline Başkalarına karşı mesafeli biriyim. & 641 & & & & & \\
\hline Duygusal Denge & & 2,967 & 12,422 & ,708 & ,863 &, 547 \\
\hline Yardımsever, çıkarcı olmayan biriyim. & ,762 & & & & & \\
\hline Umursamaz biriyim. & ,717 & & & & & \\
\hline Enerji dolu biriyim. & ,711 & & & & & \\
\hline Duygusal olarak dengeli, kolaylıkla morali bozulmayan biriyim. & 664 & & & & & \\
\hline Soğuk ve mesafeli olabilen biriyim. & 621 & & & & & \\
\hline Gergin olabilen biriyim. & 620 & & & & & \\
\hline Hayal gücü yüksek biriyim. & ,602 & & & & & \\
\hline Sorumluluk & & 3,517 & 9,074 & ,788 & 806 & 628 \\
\hline Planlar yapan ve bu planları uygulayabilen biriyim. & ,780 & & & & & \\
\hline İşlerini verimli ve tam olarak yapabilen biriyim. & ,745 & & & & & \\
\hline Rutin, sabit bir düzeni olan işleri yapmayı seven biriyim. & 676 & & & & & \\
\hline Başladığı işi tamamlayabilen biriyim. & 674 & & & & & \\
\hline Çok endişelenen biriyim. & 632 & & & & & \\
\hline İşini eksiksiz yapan biriyim. & 625 & & & & & \\
\hline Deneyime Açıklık & & 3,062 & 5,564 & ,775 & 918 & 684 \\
\hline Sanata ve estetik değerlere önem veren biriyim. & ,731 & & & & & \\
\hline Düşünmeyi seven, fikirler geliştirebilen biriyim. & ,636 & & & & & \\
\hline Başkalarıyla iş birliği yapmayı seven biriyim. & 621 & & & & & \\
\hline Sanat, müzik ve edebiyatta çok bilgili olan biriyim. & 608 & & & & & \\
\hline \multicolumn{7}{|c|}{ KMO =0,719 Toplam Açıklanan Varyans: 79,706 } \\
\hline
\end{tabular}

faktör kişilik özelliklerinin sürdürülebilir çevre davranışları üzerindeki etkisinin belirlenmiştir.

Beş faktör kişilik özellikleri, turizmde sürdürülebilir çevre davranışlarının yüzde 57,1'ini açıklamaktadır ( $F=87,833 ; p<0,001)$. Değişkenler arasında çoklu bağlantı probleminin bulunup bulunmadığını belirlemek amacıyla tolerans ve varyans artış değerleri de (VIF) analiz edilmiştir.
Çoklu bağlantı probleminin olmaması için tolerans değerinin de 0,2 'nin üstünde ve VIF değerinin 10'un altında olması gerekmektedir. Tabloda tolerans değerleri 0,2'den büyük ve VIF değerlerinin de 10'dan küçük olduğu görülmektedir. Uyumluluk, duygusal denge ve deneyime açıklık kişilik özelliklerinin istatistiksel olarak sürdürülebilir çevre davranışlarını etkilemediği belir- 
Tablo 4. Sürdürülebilir Çevre Davranışı Faktör Analizi Sonuçları

\begin{tabular}{|c|c|c|c|c|c|c|}
\hline Faktörler & $\begin{array}{l}\text { Faktör } \\
\text { Yükleri }\end{array}$ & Özdeğer & $\begin{array}{r}\text { Açıklanan } \\
\text { Varyans (\%) }\end{array}$ & $\begin{array}{l}\text { Alpha } \\
\text { Değeri }\end{array}$ & $C R$ & $A V E$ \\
\hline Sürdürülebilir Çevre Davranışları & & 3,348 & 74,534 & ,780 & 848 & 622 \\
\hline $\begin{array}{l}\text { Seyahatimi çevresel sorumluluğu destekleyen seyahat } \\
\text { acentalarıyla yaparım }\end{array}$ & 789 & & & & & \\
\hline Seyahatimde doğada çözülebilir ambalajlı ürünler kullanırım. & 761 & & & & & \\
\hline $\begin{array}{l}\text { Seyahatimde tura katılanları çevreye zarar verecek ürünleri } \\
\text { kullanmamaları konusunda uyarırım. }\end{array}$ & 701 & & & & & \\
\hline $\begin{array}{l}\text { Seyahatimde enerji tasarrufu sağlayan ürünler kullanırım } \\
\text { Seyahatimde daha az elektrik harcayan elektronik } \\
\text { cihazları satın alırım. }\end{array}$ &, 672 & & & & & \\
\hline
\end{tabular}

Seyahatimde karton, teneke ve cam gibi ürünleri geri dönüşüm için değerlendiririm.

KMO =0,764 Toplam Açıklanan Varyans: 74,534

Tablo 5. Değişkenlere Ait Korelasyon Analizi Sonuçları

\begin{tabular}{|c|c|c|c|c|c|c|}
\hline & 1 & 2 & 3 & 4 & 5 & 6 \\
\hline 1.Dışa Dönüklük & (1) & & & & & \\
\hline 2.Uyumluluk & $0,240^{*}$ & (1) & & & & \\
\hline 3.Duygusal Denge & $0,532^{*}$ & $0,663^{*}$ & (1) & & & \\
\hline 4.Sorumluluk & $0,414^{*}$ & $0,296^{*}$ & $0,628^{*}$ & (1) & & \\
\hline 5.Deneyime Açıklık & $0,302^{*}$ & $0,196 *$ & $0,274^{*}$ & $0,366 *$ & (1) & \\
\hline 6.Sürdürülebilir Çevre Davranışları & $0,253^{*}$ & $0,537^{*}$ & $0,729 *$ & $0,630^{*}$ & $0,441^{*}$ & (1) \\
\hline Cronbach's Alpha & ,715 & ,725 & ,708 & ,788 & ,775 & ,780 \\
\hline Standart Sapma & 801 & 820 & ,674 & ,752 & 848 & ,722 \\
\hline Ortalama & 3,680 & 3,844 & 3,582 & 3,820 & 3,482 & 4,068 \\
\hline
\end{tabular}

Tablo 6. Değişkenlere Ait Regresyon Analizi Sonuçları

\begin{tabular}{|c|c|c|c|c|c|c|c|}
\hline \multirow[t]{2}{*}{ Değişkn } & \multicolumn{2}{|c|}{$\begin{array}{l}\text { Standardize } \\
\text { Edilmemiş } \\
\text { Katsayılar }\end{array}$} & \multicolumn{2}{|c|}{$\begin{array}{l}\text { Standart } \\
\text { Katsayılar }\end{array}$} & \multirow[t]{2}{*}{$\mathrm{p}$} & \multirow[t]{2}{*}{ Tolerans } & \multirow[t]{2}{*}{ VIF } \\
\hline & $\beta$ & Std. Hata & $\beta$ & $\mathrm{t}$ & & & \\
\hline Sürdürülebilir Çevre Davranışları & (Sabit) & 1,004 & 0,102 & & 9,360 & 0,000 & \\
\hline Dışa Dönüklük & 0,623 & 0,052 & 0,681 & 10,097 & 0,000 & 0,211 & 4,513 \\
\hline Uyumluluk & 0,045 & 0,033 & 0,069 & 1,136 & 0,080 & 0,304 & 3,862 \\
\hline Duygusal Denge & 0,028 & 0,039 & 0,071 & 1,687 & 0,072 & 0,282 & 3,664 \\
\hline Sorumluluk & 0,568 & 0,027 & 0,618 & 9,894 & 0,000 & 0,318 & 4,227 \\
\hline Deneyime Açıklık & 0,084 & 0,046 & 0,057 & 0,963 & 0,076 & 0,201 & 5,006 \\
\hline
\end{tabular}

$\mathrm{R}=0,754 ; \mathrm{R} 2=0,571 ;$ Düzeltilmiş R2=0,564; $\mathrm{F}=87,833 ; \mathrm{Sig}=0,001$ 
lendiği için $\mathrm{H}_{2}$, $\mathrm{H}_{3}$ ve $\mathrm{H}_{5}$ hipotezleri reddedilmiştir. Dışa dönüklük $(\beta=, 623 p=, 000)$ ve sorumluluk $(\beta=, 568 p=, 000)$ kişilik özellikleri sürdürülebilir çevre davranışları üzerinde anlamlı bir etkiye sahip olduğu belirlenmiş ve $\mathrm{H}_{1}$ ile $\mathrm{H}_{4}$ hipotezleri kabul edilmiştir.

\section{SONUC}

Turizmde çevrenin sürdürülebilirliği ve sonraki nesillere en az olumsuz etkiyle aktarılması önemlidir. Bu açıdan turistlerin gittikleri destinasyonda çevreye karşı duyarlı olmaları, olumsuz davranışlardan kaçınmaları gerekmektedir. Destinasyonlarında sürdürülebilirlik hem akademisyenler hem de destinasyon yöneticileri tarafından üzerinde durulan öncelikli konular arasında yer almaktadır. Bu araştırmada yurt dışına çıkan yerli turistlerin beş faktör kişilik özelliklerinin, turizmde sürdürülebilir çevre davranışları üzerindeki etkisi incelenmiştir.

Araştırma sonuçları beş faktör kişilik özelliklerinin turizmde sürdürülebilir çevre davranışları üzerinde pozitif etkisinin olduğunu ortaya koymuştur. Yapılan korelasyon analizi sonuçları tüm faktörlerin turizmde sürdürülebilir çevre üzerinde olumlu ve pozitif yönlü bir ilişkinin olduğunu ortaya çıarmıştır. Bu sonuç turistlerin kişilik özellikleri nasıl olursa olsun, tur sırasında gittikleri destinasyonda çevreye karşı duyarlı davrandıklarını göstermektedir.

Yapılan regresyon analizleri sonucunda dişa dönüklük kişilik özelliğinin, turizmde sürdürülebilir çevre davranışları üzerinde anlamlı bir etkisinin olduğunu göstermiştir. Bu sonuçla $\mathrm{H}_{1}$ hipotezi kabul edilmiştir. Bu sonuç Kvasova (2015) çalışmasıyla aynı sonucu ortaya koymuştur. Turistlerin enerjik, konuşkan, sıcakkanlı, heyecanlı ve sosyal olma gibi dışa dönük kişilik özellikleri, turizmde sürdürülebilir çevre üzerinde olumlu etkiye sahiptir. Sosyal olma eğilimi gösteren turistler bu tutum ve davranışlarını gittikleri destinasyonda sergilemekte ve kendi ev sahibi oldukları ülkede oldukları gibi gittikleri destinasyonda da çevreye karşı duyarlılıklarını korumaktadırlar.

Araştırmanın bir diğer sonucun da uyumluluk kişilik özelliğinin, turizmde sürdürülebilir çev- re davranışları üzerinde etkisinin olmadığıdır. $\mathrm{Bu}$ sonuçla $\mathrm{H}_{2}$ hipotezi reddedilmiştir. Bu sonuç Yu ve Yu (2017), Kvasova (2015), Hirsh (2010) ve Milfont ve Sibley'nin (2012) çalışmalarıyla benzer sonuçları ortaya koymamıştır. Uyumluluk kişilik özelliğine sahip turistler, sürdürülebilir çevre üzerinde olumlu bir etkiye sahip değildirler. Yurt dışına çıkan yerli turistler, sempatik, sevecen, sıcakkanl, yardımsever olma gibi uyumluluk kişilik özelliklerini öncelikli olarak çevreye karşı değil, gittikleri destinasyondaki yerel halkla olan ilişkilerinde gösterdikleri anlaşılmaktadır.

Araştırmada duygusal denge kişilik özelliğinin, turizmde sürdürülebilir çevre davranışları üzerinde etkisinin olmadığını ortaya çıkmış ve $\mathrm{H}_{3}$ hipotezi reddedilmiştir. Bu sonuç Hirsh (2010) ve Milfont ve Sibley'nin (2012) çalışmalarıyla aynı sonuçları ortaya koymuştur. Turistlerin endişeli, güvensiz, kaygılı, karamsarlık gibi duygusal denge kişilik özellikleri, gittikleri destinasyonda sürdürülebilir çevre davranışlarını etkilememektedir. Yurt dışına çıkan yerli turistler daha çok kendileri ile ilgili tutum ve davranışlara öncelik vermekte ve turizmde sürdürülebilir çevre davranışlarını göz ardı etmektedirler.

Yapılan analizler sonucunda sorumluluk kişilik özelliğinin, turizmde sürdürülebilir çevre davranışları üzerinde anlamlı bir etkisinin olduğunu göstermiştir ve $\mathrm{H}_{4}$ hipotezi kabul edilmiştir. Görev bilinciyle hareket etme, bilinçlilik, düzenlilik, etkili olma, planlılık gibi sorumlu kişilik özelliklerine sahip turistler, yurt dişında da bu sorumluluklarını yerine getirmekte ve turizmde sürdürülebilir çevre davranışlarını sergilemeye devam etmektedirler. Bu sonuç ayrıca Milfont ve Sibley (2012) ve Kvasova'nın (2015) çalışmalarıyla da benzer sonuçları ortaya koymuştur.

Bir diğer araştırma sonucuna göre deneyime açıklık kişilik özelliğinin, turizmde sürdürülebilir çevre davranışları üzerinde etkisinin olmadığıdır. Bu sonuçla $\mathrm{H}_{5}$ hipotezi reddedilmiştir ve Milfont ve Sibley'nin (2012) çalışmasıyla benzer sonuçları ortaya çıkarmıştır. Analitik düşünen, meraklı, yaratıcı, bağımsız olma gibi özelliklere sahip deneyime açık kişilik sahibi turistlerin, sürdürülebilir çevre davranışlarına öncelik verme- 
den, deneyime açık yönlerini yeni şeyler öğrenme, yeni kültür tanıma gibi konularda kullandıkları düşünülmektedir.

\section{DEĞERLENDIRME}

Beş faktör kişilik özelliklerinin turizmde sürdürülebilir çevre davranışları üzerindeki etkisinin incelendiği bu çalışmada alanyazına katkı sağlayacağı düşünülen önemli sonuçlar ortaya çıkmıştır. Çalışmanın, bu alanda yapılan çalışmaların kısıtlı olması nedeniyle ileride yapılacak olan çalışmalara da yol göstereceği düşünülmektedir. İleriki yıllarda yapılacak olan çalışmalarda yerli ve yabancı turistlerin tutum ve davranışları incelenebilir. Türkiye'ye gelen yabancı turistlerin kişilik özelliklerinin çevre davranışları üzerindeki etkisi incelenebilir. Benzer şekilde yurt dışına çıkan yerli turistlerin tutum ve davranışlarındaki değişimler de incelenmeye devam edilebilir. Araştırma Türkiye'deki diğer seyahat acentaları üzerinde de çalışma yapılarak geliştirilebilir.

Turizm sektöründe yer alan kurum ve kuruluşlar, destinasyonlarını ziyaret eden turistlerin beş faktör kişilik özellikleri ile sürdürülebilir çevre davranışları arasındaki ilişkiyi incelemek suretiyle, destinasyonlarının sürdürülebilirliğini sağlamada önemli verilere ulaşabilir ve turistlerin bu yönde tutum ve davranışlarını öğrenerek bu yönde bölgesel gelişimlerini sağlayabilirler. Bu beklentilerin, tutum ve davranışların belirlenmesi ile destinasyonun korunması ve gelecek nesillere korunmuş bir şekilde aktarılması sağlanabilir. Ayrıca destinasyonun gelişimi de bu araştırmalar sonucunda sağlıklı bir şekilde yapılabilir.

Turizmin kitlesel hareketliliğinden yoğun bir şekilde etkilenen destinasyonlarda çalışan yöneticiler, beş faktör kişilik özellikleri ile çevrenin korunması ve gelecek nesillere aktarılmasında bireysel çözümler sağlayabilirler. Özellikle yerel yöneticiler, yoğun turizm hareketliliklerinin ortaya çıkardığı çevre zararlarını bu şekilde en az indirgeyebilirler. Yerel yöneticiler, kitle turizmi yerine daha bireysele indirgenecek özel ilgi turizm türlerine yönelebilir ve kişilik özellikleriyle destinasyonlardaki çekicilik unsurları arasındaki ilişkiyi ortaya çıkaracak araştırmalar yapabilirler.

\section{KAYNAKÇA}

Akgündüz, Y., Dalgıç, A., Kale, A. ve Karakan, H. İ. (2015). Beş Faktör Kişilik Özelliklerinin Dönüşümcü Liderlik Davranışlarına Etkisi: Otel İşletmelerinde Bir Araştırma, Uluslararası Alanya İşletme Fakültesi Dergisi, 7(3): 83-97.

Altanlar, A. ve Akıncı Kesim, G. (2011). Sürdürülebilir Turizm Planlaması için Yöre Halkı ve Yerli Turistlerin Davranıș ve Beklentilerini Anlamaya Yönelik Bir Araştırma; Akçakoca Örneği, Ankara Üniversitesi Çevrebilimleri Dergisi, 3(2):1-20.

Ashton M.C. ve Lee, K. (2008). The Prediction of HonestyHumility-Related Criteria by the HEXACO and FiveFactor Models of Personality, Journal of Research in Personality, 42(5): 1216-1228.

Asmelasha, A. G. ve Kumar, S. (2019). Assessing Progress of Tourism Sustainability: Developing and Validating Sustainability Indicators, Tourism Management, 71(Nisan): $67-83$.

Aslan, Z., Ünüvar, Ş. ve Başoda, A. (2012). Turizm Eğitimi Alan Öğrencilerin Kişilik Özelliklerinin Belirlenmesi ve Turizm Sektörüne Uyumu Açısından Değerlendirilmesi, Anatolia: Turizm Araştırmaları Dergisi, 23(2): 203219.

Avcıkurt, C., Karaman, S. ve Ceylan, U. (2017). Çevresel Olarak Sürdürülebilir Turist Davranışları: İstanbul'a Gelen Turistler Üzerine Bir Araştırma, VI. Ulusal-II. Uluslararası Doğu Akdeniz Turizm Sempozyumu, Gaziantep, 1415 Nisan 2017.

Barrick, M. R. ve Mount, M. K. (1991). The Big Five Personality Dimensions and Job Performance: A Meta-Analysis, Personnel Psychology, 44: 1-26.

Bertan, S. (2009). Turizmin Çevre Üzerinde Yarattığ Pamukkale Örneği, Anatolia: Turizm Araştırmaları Dergisi, 20(2): 204-214.

Bramwell, B. ve Lane, B. (1993). Sustainable Tourism: An Evolving Global Approach, Journal of Sustainable Tourism, 1(1): 1-5.

Church, A. T., Reyes, J. A. S., Katigbak, M. S. ve Grimm, S. D. (1997). Filipino Personality Structure and the Big Five Model: A Lexical Approach, Journal of Personality, 65(3): 477-528.

Clark, C. F., Kotchen, M. J. ve Moore, M. R. (2003). Internal and External Influences on Proenvironmental Behavior: Participation in a Green Electricity Program, Journal of Environmental Psychology, 23(3): 237-246.

Costa P. T. Jr. ve McCrae, R. R. (1990). Personality Disorders and The Five-Factor Model of Personality, Journal of Personality Disorders, 4(4): 362-371.

Çalışkan, C. (2017). Sürdürülebilir Turizmin Çevre İkilemi: Toplum ve Tüketim, İnsan ve Toplum Bilimleri Araştırmalarl Dergisi, 6(2): 1123-1136.

Çetin, S. A. (2018). Aşçıların Beş Faktör Kişilik Özellikleri, Bireysel İnovasyon Algısı, Bireysel İnovasyon Davranış1 İlişkisi: Bursa Örneği (Basılmamış Doktora Tezi). Balıkesir: Balıkesir Üniversitesi, Sosyal Bilimler Enstitüsü, Turizm İşletmeciliği ve Otelcilik Ana Bilim Dalı.

Dinan, C. ve Sargeant, A. (2000). Social Marketing and Sustainable Tourism - Is There a Match?, International Journal of Tourism Research, 2(1): 1-14. 
Goldberg, L. R. (1990). An Alternative Description of Personality: The Big-Five Factor Structure, Journal of Personality and Social Psychology, 59(6): 1216-1229.

Hirsh, J.B. (2010). Personality and Environmental Concern, Journal of Environmental Psychology, 30: 245-248.

Islam, M. ve Managi, S. (2019). Green Growth and Proenvironmental Behavior: Sustainable Resource Management Using Natural Capital Accounting in India, Resources, Conservation \& Recycling, 145(Haziran): 126138.

John, O. P., Donahue, E. M. ve Kentle, R. L. (1991). The BigFive Inventory-Version $4 a$ and 54 . Berkeley, CA: University of California, Institute of Personality and Social Research.

Juvan, E. ve Dolnicar, S. (2014). The Attitude-Behaviour Gap in Sustainable Tourism, Annals of Tourism Research, 48(Eylül): 76-95.

Juvan, E. ve Dolnicar, S. (2016). Measuring Environmentally Sustainable Tourist Behaviour, Annals of Tourism Research, 59(Temmuz): 30-44.

Karaca, Ş. (2018). Yaşam Tarzının Sürdürülebilir Tüketim Davranışı Üzerindeki Etkisini Belirlemeye Yönelik Bir Çalışma, İşletme Araştırmaları Dergisi, 10(3): 403-425.

Kastenholz, E., Eusébio, C. ve Carneiro, M. J. (2018). Segmenting the Rural Tourist Market by Sustainable Travel Behaviour: Insights from Village Visitors in Portugal, Journal of Destination Marketing \& Management, 10(Aralik): 132-142.

Kozak, N., Özel, Ç. H. ve Karagöz Yüncü, D. (2014). Hizmet Pazarlaması. Ankara: Detay Yayıncilik.

Krippendorf, J. (1987). The Holiday Makers: Understanding the Impact of Leisure and Travel. Wilshire, UK: Heineman Professional Publishing.

Kvasova, O. (2015). The Big Five Personality Traits As Antecedents of Eco-Friendly Tourist Behavior, Personality and Individual Differences, 83(Eylül): 111-116.

McCabe, K. O., Van Yperen, N. W., Elliot, A. J. ve Verbraak, M. (2013). Big Five Personality Profiles of Context-Specific Achievement Goals, Journal of Research in Personality, 47(6): 698-707.

Milfont, T. L. ve Sibley, C. G. (2012). The Big Five Personality Traits and Environmental Engagement: Associations at the Individual and Societal Level, Journal of Environmental Psychology, 32(2): 187-195.

Norman, W. T. (1963). Toward an Adequate Taxonomy of Personality Attributes: Replicated Factor Structure in
Peer Nomination Personality Ratings, Journal of Abnormal and Social Psychology, 66: 574-583.

Öztürk, A. (2016). Hüzün Turizmi Katılımcılarının Kişilik Özellikleri, Motivasyonları ve Memnuniyetleri Arasındaki İlişki (Basılmamış Yüksek Lisans Tezi). Antalya: Akdeniz Üniversitesi Sosyal Bilimler Enstitüsü.

Perkins, H. E. ve Brown, P. R. (2012). Environmental Values and the So-called True Ecotourists, Journal of Travel Research, 51(6): 793-803.

Pulido-Fernandez, J. I., Cardenas-García, P. J. ve EspinosaPulido, J. A. (2019). Does Environmental Sustainability Contribute to Tourism Growth? An Analysis at the Country Level, Journal of Cleaner Production, 213(Mart): 309-319.

Sheldon, P. J. ve Park, S.Y. (2011). An Exploratory Study of Corporate Social Responsibility in the U.S. Travel Industry, Journal of Travel Research, 50(4), 392-407.

Somer, O. (1998). Türkçe 'de Kişilik Özelliği Tanımlayan Sıfatların Yapısı ve Beş Faktör Modeli, Türk Psikoloji Dergisi, 13(42): 17-32.

Su,L., Swanson, S. R., ve Chen, X. (2018). Reputation, Subjective Well-Being, and Environmental Responsibility: The Role of Satisfaction and Identification, Journal of Sustainable Tourism, 26(8), 1344-1361.

Wang, C., Zhang, J., Yu, P. Ve Hu, H. (2018). The Theory of Planned Behavior as a Model for Understanding Tourists' Responsible Environmental Behaviors: The Moderating Role Of Environmental Interpretations, Journal of Cleaner Production, 194(1 Eylül): 425-434.

Wang, C., Zhang, J., Cao, J., Hu, H. ve Yu, P. (2019). The Influence of Environmental Background on Tourists' Environmentally Responsible Behaviour, Journal of Environmental Management, 231(Kasım): 804-810.

Wood, K. ve House, S. (1992). The Good Tourist: A Worldwide Guide for the Green Traveller. Londra: Mandarin.

Varnacı Uzun, F. ve Altaş, A. (2017). Kapadokya Bölgesi'ni Ziyaret Eden Turistlerin Sürdürülebilir Tüketim Davranışları, Aksaray Üniversitesi İktisadi ve İdari Bilimler Fakültesi Dergisi, 9(4): 1-10.

Yu, T. ve Yu, T. (2017). The Moderating Effects of Students' Personality Traits on Pro-Environmental Behavioral Intentions in Response to Climate Change, International Journal of Environmental Research and Public Health, 14(12): 1472: 1-20.

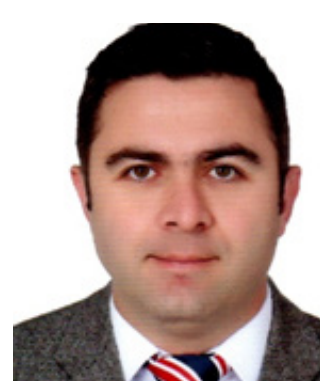

Uğur CEYLAN

Erciyes Üniversitesi Nevşehir Turizm İşletmeciliği ve Otelcilik Yüksekokulu Turist Rehberliği Bölümü'nden mezun oldu (2004). Yüksek lisans derecesini Balıkesir Üniversitesi Turizm İşletmeciliği ve Otelcilik Dalı'ndan (2013), doktora derecesini de Balıkesir Üniversitesi Turizm İşletmeciliği ve Otelcilik Dalı'ndan aldı (2017). Kütahya Dumlupınar Üniversitesi'nde öğretim Görevlisi olarak çalışmaya başladı (2010). Halen Kütahya Dumlupınar Üniversitesi, Tavşanlı Uygulamalı Bilimler Fakültesi, Turizm ve Otel İşletmeciliği Bölümü'nde görev yapmaktadır. Temel çalışma alanları, turizm pazarlama$\mathrm{SI}$, turist rehberliği ve turizm işletmeciliğidir. 